\title{
The Impact of the Arab Spring on the US Foreign Policy Towards the Hashemite Kingdom of Jordan (2010-2017)
}

\section{ABSTRACT}

\author{
Dr: Maha Habis Sami Elfayez
}

The study mainly aimed to explain the impact of the Arab spring revolutions on the orientations of the US foreign policy towards Jordan during the period 2010-2017. The study adopted the analytical descriptive approach, the study sought to confirm the validity of the following hypothesis: influenced by the revolutions of the Arab Spring on foreign political trends towards the Hashemite Kingdom of Jordan.

The study concluded that the US foreign policy towards Jordan views its relationship with Jordan through a set of objectives, including the mutual and comprehensive goals of achieving a lasting peace in the Middle East. Jordanian-American relations were based on strategic, security and political dimensions has increased the American interest in the Jordanian issue, as the study showed the impact of the military factors in Jordanian-US relations, and this is shown by the Jordanian role in the fight against terrorism and extremism. The study recommends the strengthening of Arab-American relations and the Jordanian-American relations and the development of Jordan's foreign policy for a clear strategy in the administration of Jordanian-US relations, thus enhancing security and stability in Jordan.

Keywords: Arab Spring. US Foreign Policy, The Hashemite Kingdom of Jordan.

DOI: $10.7176 /$ PPAR/10-2-08

Publication date: February $29^{\text {th }} 2020$

\section{Introduction}

The US foreign policy is working to implement its strategies in the Arab region within a clear and specific vision of adopting soft or hard power tools or combining them using smart power, and influencing the make of American foreign policy on internal and external variables and determinants, The developments in the Middle East in the wake of the 2011 Arab Spring revolutions have prompted renewed calls for a fundamental reassessment of major US trends and American interests in the region. And the appropriate political policies to achieve them, On the other hand, the Jordanian-American relations were distinguished from their beginning, more than half a century ago, as they were based on mutual interests between the two countries. In various political, economic and security aspects, In spite of the economic and military assistance Jordan receives from the United States, Political relations and mutual understandings on major issues in the region remain more important and influencing the stability of Jordan and the Arab region. What distinguishes Jordanian-American relations in its political division is that they are not private relations. Most of the political issues that are placed on the table of Jordanian-American meetings and talks are issues of Arab proportions. It focuses in particular on the Palestinian portfolio. American foreign policy has witnessed strategic shifts after the erupt of the demonstrations in the Arab world which is known as the Arab spring, that turned the American desire to refrain from direct interference in Arab issues; Hence, this study came to discuss the American foreign policy towards Jordan and its level of vulnerability to the protests and transformations that Arab countries have witnessed since 2011.

\section{Study problems:}

This study examines the US foreign policy towards the region in the Arab Spring period and towards Jordan in particular. Therefore, the study came to discuss the issue of American foreign policy orientations towards Jordan during the Arab Spring period, the changes that have taken place in the Arab region have also affected the orientation of American policy in the Arab region. From this point, the study seeks to answer the following main question: What is the level of impact the Arab Spring revolutions made on the orientations of American foreign policy towards Jordan during the period 2010-2018? The following sub-question is branched from it: What is the level of impact the Arab Spring revolutions made on the orientations of American foreign policy toward Jordan?

\section{Study aims:}

This study aims mainly to clarify the impact of the Arab Spring revolutions on the orientations of American foreign policy towards Jordan during the period 2010-2018. And the level of impact Arab Spring made on the orientations of American foreign policy towards Jordan.

\section{Study hypotheses:}

This study is based on a major hypothesis that: The Arab Spring revolutions affected the orientations of American foreign policy towards the Hashemite Kingdom of Jordan. 


\section{The importance of the study:}

The importance of the study stems from the scientific and practical aspects from the following:

1- Scientific Importance: The scientific significance of the study stems from its effort to analyze the orientations of American foreign policy towards the Hashemite Kingdom of Jordan in the period (20102018). Under the influence that the US is gaining in the political transformations witnessed by the Arab region in general, and Jordan in particular during the period 2010-2018.

2- The practical importance: The practical importance of the study is highlighted by the results of the study, and how it represent the orientations of the American foreign policy towards Jordan, given the scarcity of studies and research covering the subject of the study, the time period it deals with. Therefore, the study can be an opportunity for those interested and those following Arab and international affairs, in order to learn about the implications of the Arab Spring on American foreign policy towards Jordan.

\section{Study Approach:}

This study relied on the following approaches in answering its questions:

Descriptive and analytical approach: This approach was used to clarify the nature of American foreign policy and its attitudes towards the Arab region in the Arab Spring period and to analyze its foreign policy towards Jordan.

The decision-making approach: This approach was used to analyze and study the determinants and decisionmaking mechanisms in American foreign policy towards the Arab Spring countries in general, and Jordan in particular.

\section{Terminology of study:}

The Arab Spring: The Arab Spring revolutions are defined as a very important historical transformation the Arab region witnessed it since 2011, starting with the revolution in Tunisia. Then it moved to Egypt, Libya, Yemen and Syria, There are researchers who define the Arab Spring as a revolutionary protests and not partial demands or temporary uprisings. Therefore, those elements of the revolutionary situation apply to Tunisia, Egypt, Libya, Yemen and Syria. As for other Arab countries, they are closer to cases of protest, just as they are closer to bold demand movements than to comprehensive revolutionary characteristics (Rashid, 2011: 14).

For the purposes of the study, the Arab Spring is known procedurally: as a group of revolutions that swept the Arab region and civil revolutions at the end of 2010, which played a crucial role in redirecting events in the Arab region.

American foreign policy: It is a term referring to the actions of the United States of America and the decisions it makes. To achieve its goals in the Arab region, by ensuring the security and protection of American interests in the Arab region in general, providing complete security in the Arab Gulf region in particular, which confirms the continued flow of oil, which represents two thirds of the world's reserves. In addition to ensuring Israel's security, military and technological superiority over Arab countries. This enables it to play its vital role within the framework of the US strategy, both regionally and globally, as an integral part of American national security (Majzoub, 2001: 103-104). Procedurally known: It refers to the behavior of decision makers in the United States of America in its relations with Jordan.

Jordanian Foreign Policy: It regulates the activity of the Jordanian state in its relations with other countries, with the aim of achieving its national interest by achieving security and stability for it, and achieving economic well-being for citizens of the state. (Al-Mashagab, 2017) Procedurally defined: It refers to the behavior of decision-makers in the Hashemite Kingdom of Jordan in its relations with the United States of America.

\section{Previous studies:}

Previous studies were presented as follows:

\section{Arabic studies:}

Mansour Abu Kareem study (2017) entitled: "The most prominent features of American foreign policy towards the Middle East region after Trump's victory". The study aimed to analyze President Trump's attitudes toward the Middle East region, The study concluded that US foreign policy under Trump is still in the making, Because the assistant team for the new US president has not been fully clear yet, and the contradiction in some statements and political positions of the new president on many issues in the Middle East during the American presidential elections, and that the United States' foreign policy towards the East under President Trump's rule 
will not be an extension of George W. Bush's policy through rough power, or as a continuation of Barack Obama's policy through soft power, it will be a cross between both policies.

Khasawneh Study (2006) entitled: "Jordan's Relations with the United States of America". The study examined Jordan's political, economic, military and security relations with the United States of America, during the period from 1999, when His Majesty King Abdullah II assumed his constitutional powers, until 2006. The researcher concluded a set of results, the most important of which are: The importance of Jordan's geo-political site, Due to its presence in the heart of the Middle East which has not witnessed stability for various reasons, The most important of them: the Arab-Israeli conflict, and the presence of the world's largest reserves of oil in it, so the researcher had to choose between all the difficult options, and to face pressures that may be difficult for countries larger than its size and possibilities to deal with it successfully.

Al-Shobaki's Study (2004), entitled "Jordanian-American Relations 1956-1998". The study emphasized that Jordanian-American relations have been extremely important since the emergence of American interest in the region, Especially after the weakness of Britain and France rule in the region, and the departure of old colonialism from the region. Where the United States became the dominant power after its exit from World War II with tremendous economic power. Its interest shifted towards the Arab region in general and Jordan in particular for fundamental reasons, including: economic, political, security and geographical, like the long borders Jordan has with Israel, and how it is closely related to the Palestinian issue. The results of the JordanianAmerican relations played a vital role in the process of making events and the way they are conducted. This importance prompted us to study these relationships historically, politically and economically, to reach logical results for them, and the challenges and problems faced by this relationship.

\section{Foreign studies:}

Jeffsdev and Takih's study (Jeffsdev \& Take, 2012) entitled: "Transformations of US policy in the Middle East after the revolutions". This study aimed to clarify the most important changes witnessed by the American policy in the Middle East after the Arab Spring revolutions, and among the results of the study, The revolutions in the Arab world led to a shift in the American position with the Obama Declaration "The interests of the United States of America are not hostile to the hopes of the people" This represents a real shift in American attitudes, as the study showed a change in its foreign policies based on humanitarian considerations.

(Bensahel and Daniel,2004) entitled: "The Future Security Environment In The Middle East". The study dealt with a set of political concepts that include conflict, stability and political changes. The study focused on the security threats experienced in the Middle East after the second Gulf War (1991), which led to instability in the region, and created political, economic and humanitarian crises, all that increased the counter-threats to the United States, and then led to the terrorist attack in September 2001.

What distinguishes this study from previous studies: This study is distinguished from previous studies by being a recent and domestic study, which examines the topic of the relationship between the Arab Spring revolutions and the American foreign policy toward Jordan. The current study is also distinguished by the time period it covers (2010-2018), as this period included major political developments in the Arab region. Within the limits of the researcher's knowledge, I did not find a recent study on American-Jordanian relations in the Arab Spring period that includes the current study period (2010-2018).

\section{American-Jordanian relations according to the American and Jordanian vision:}

The Jordanian-American relations can be analyzed under the schools and theories that define the features of American foreign policy in the Arab region in general and towards Jordan in particular, which can be summarized as follows:

- Realistic school: it is based on achieving the principle of preserving the national interest, regardless of the methods used, even the necessity of using military power. The primary interest of this school is the interest of the United States, to have contributions and a role in international organizations if they serve the interests of states in general, Regardless of the intellectual perspective, whether it is Unilateralist or Multilateralist. This school deals with other countries in its external relations from the perspective of calculation and cost. That is, on the principle of the rational actor model, as the United States has interests in maintaining political stability in Jordan because of its reflection on the Arab region. The Jordanian-American relations were launched at the beginning of Jordan's position rejecting the communist tide, and opponents of the influence of the Soviet Union for ideological reasons, from the US's interest in Jordan for strategic reasons, as it has a distinguished geographical location from which it can benefit in implementing its foreign policy in the region, and its geographical borders with Israel, Syria, and Iraq (Al-Hajjaj, 2009).

- The Ideal School: It is an American school of thought based on the importance of adhering to international law, and on what should be in international relations. It calls for more arms control, for using peaceful and 
diplomatic tools to resolve international conflicts. It is largely a predominant approach to European politics. It also strongly believes in the role of international institutions. (Macridis, 1986).

- Since Jordan's policy is characterized by moderation and adherence to international law and agreements, and seeks to limit the spread of nuclear weapons or weapons of mass destruction in the Arab region, it is in line with the US strategy towards the Arab region.

- $\quad$ The Arab School (a mixture of idealism and Marxism): The school focuses on the importance of achieving peace and development in international relations. It is a school that assumes that war and conflict are the exception, and that cooperation and peace are the foundation in international relations, it is a school that restores everything that happens to the role of the external factor, and adopts the negative or marginal role, and the inefficiency in international relations (Al-Hayajnah, 2006).

- Whereas, Jordan's foreign policy focuses on achieving peace and development in Jordan and the Arab region, seeks to resolve the Arab-Israeli conflict, achieve peace and development in Syria and Iraq, and this appears to be consistent with American interests in the Arab region.

- The International School (which combines realism and idealism): This school focuses on the importance of building international economic systems between countries, that rests with the dominant state, which is not necessary to continue, and focuses on globalization, and the importance of international interaction, without losing sight of the role of military means in international relations, which see that war has become a thing of the past. This indicates the importance of the exchange of interests between the United States and Jordan in economic terms. Jordan depends on the aids that the US provide to it and the export of Jordanian products to America.

- Since the 1950s, Jordanian foreign policy towards America has gone through several stages, It was based on the knowledge of the political decision-maker in the Hashemite Kingdom of Jordan about the importance of the American rule in the world in general to the extent of its influence on Arab issues, and its most important role in the Palestinian case in particular. The most prominent goals of Jordan's foreign policy toward America were to serve the Palestinian cause, preserving the rights of the Palestinian people, meeting their aspirations for a just peace, and establishing an independent state, In addition to strengthening Jordanian-American relations and strengthening the Jordanian political role in the region, and to protect Jordan from external threats and to provide aid, grants and loans that enhance stability in Jordan.

\section{Jordan's importance in relation to American foreign policy in the Arab region:}

As long as King Abdullah II is one of the closest US allies in the region, one of the first world leaders to offer assistance and support to the United States of America after the attacks of September 11, 2001, This support came in many forms that include supposed intelligence activities, operational coordination, continuous deployment of Jordanian military personnel in Afghanistan since 2001 (Sharp, 2012: 16), King Abdullah II was also the largest supporter of moderate Islam in the Arab world, As expressed in the Amman Message 2004 (King Abdullah II, 2007: 215-224), As a result of his moderate and unified advocacy of Islam, which made him respected by religious and political leaders around the world, This enabled him to act as a mediator between the United States and other Arab countries, between the Israelis and the Palestinians, and between Muslim, Jewish and Christian societies all over the world.

\section{Jordanian perspective on its relations with the United States of America:}

The Jordanian perspective on international relations and its relations with the United States of America can be explained from the perspective of the pragmatic school, where the political Jordanian order realizes, Jordan is a crucial country in the international relations system and the Arab region, it acts on the basis of the supreme national interest, understands the distribution of power in the international system, and sees the importance of international organizations and international law, But Jordan believes that keeping its strength is the basis, and from this perspective it also sees that the United States of America behaves in its international relationship from the perspective of its national interest, Because of its advance in military, economic and technological aspects compared to the rest of the great powers, it is noted from the behavior of Jordan government that if follows the concept of doing necessary measure in the short term, which may not be acceptable towards its people in order to achieve major goals, which can be seen in the Jordanian government behavior towards American interest in the region, Like the situation in Iraq or Palestine. The Jordanian government supports reform and change in the Palestinian approach in order to achieve a greater goal, which is the establishment of Palestinian states. In Iraq, the Jordanian government welcomed the formation of the interim Iraqi government, and is dealing with it in order to lead to the departure foreign forces from the region, But the Jordanian government cannot publicly declare all this, As a result of the negative repercussions of Jordanian 
public opinion, which sometimes does not understand the Jordanian dimension and pragmatic perspective; For example: Former Prime Minister "Faisal Al-Fayez" said that Jordan is ready to cut ties with the United States of America if an Arab country provides Jordan with the same level of assistance the United States of America provides to Jordan.

There are a number of views on international interest in the Arab region. The great powers, especially the United States of America, should withdraw from the region. Because it only brought trouble to the region from there point of view, such as the American war on Iraq, without any international or legal legitimacy, and the presence of more than 150,000 American soldiers in the region. In addition to imposing reform projects that serve American interests in the region, Such as: The Greater Middle East Project, while others believe that international interest has some of the positives that it can offer the region, because lack of interest in the region will mean a decline in the importance of the region, It needs external support and attention from the world to help it deal with the challenges it faces, On this basis, the Jordanian leadership dealt with preserving the American interest in the region, because of the active role of the US in the region in various fields, including: the peace process, resolving the Palestine-Israeli conflict, political stability in Iraq, achieving development goals and so on.

It seems that the geographical position of Jordan made it adopt to this reality, as working with its negative impacts and dealing with those impact as a positive sign to build the American Jordanian relation, Therefore, the importance of the geographical location was based on many things, including: the Jordanian regional role, and the major political role played by Jordan, so the Jordanian geographical location is not a negative factor but rather a positive factor in Jordanian-American relations; so Jordan deals with this reality to strengthen Jordanian-American relations, Especially since the United States of America has close relations with Israel, which is a security related issue to Jordan, it also has major interests in Jordan's strategic neighbor Saudi Arabia, and the role that the neighboring Jordan sites can play in American attitudes toward the Syrian crisis, in addition to the major rule expected from America in resolving the Arab-Israeli conflict, as well as the Greater Middle East project, in which Jordan considers a reform model that should be emulated by the Arab and Islamic countries targeted in this project.

Jordan has understood this equation greatly in its dealings and relations with America, just as America has understood the important position of Jordan, and the role it can play towards American interests. America has a major strategic project in the Arab region. This project came in the form of several outwardly separate projects such as: democracy and human rights in the Arab world, economic development, creating a free Middle Eastern market, political reform, and countering terrorism, But it is in fact an integrated project agreed upon by all the forces that influence the making of American foreign policy, and if there are divergent views on the mechanism to achieve it, therefore, Jordan understood these American directions, starting with the national security strategy of America, which was published in September 2002, King Abdullah II suggested that a "Marshall Plan" for the Arab region be thought of that includes all the elements that the United States of America talks about, as the "Marshall Plan", which was implemented to rebuild Europe and Japan after World War II, It was not a purely economic plan but rather a political plan whose primary goal was to establish similar political systems in all the targeted countries, based on the foundations of democracy, so that political decisions in them are not subject to the personal moods of political leaders, but rather are based on an institutional process and the individual's participation in decision-making, and building these countries in an economically American standards, including a free market economy (Prados, 2003).

\section{American prospects towards its relation with Jordan:}

The United States of America based its relationship with Arab countries on the strategy it published in 2002, which affected its foreign policy in the Arab region, the overall US foreign policy positions can be summed up with the following (Hayajana, 2006, 250-252):

First: Full support for the Israeli government in the occupation of the Palestinian territories, and for its aggressive policies towards the Palestinian people in its various forms, security, political, economic and social.

Second: The lack of effective intervention in the peace process, except in the field of diplomatic maneuvers and protocols, and the road map in which to postpone their exploitation later in the field of Arab negotiation in the post-war period in Iraq, as happened in the peace process after the first Gulf War.

Third: The occupation of Afghanistan and Iraq, and the use of all types of weapons against an economically, politically and socially backward country.

Fourth: Blackmailing the government of Pakistan and blackmailing the systems of Arab and Islamic countries directly and indirectly, with all forms of economic, political and other pressures.

On the other hand, in light of the United States of America re-arranging its cards to deal with the major emerging countries, it should not neglect the role of non-state actors from multinational companies, armed groups and militias, whose role will increase beyond the control of the governments of the nation-states. Therefore, the future and the status of the United States of America and its globally active role will be linked to 
the extent of its ability to deal with these developments that present themselves on the international scene. It can be said that the American foreign policy failed to deal with the Syrian crisis, as Syria continues to live in a state of instability, along with the increase in the activity of terrorist and extremist groups, whose threat is no longer limited to Syria and its neighboring countries, but extends to American security and interest as well. Although the war against terrorism is one of the primary issues on the American agenda. On the other hand, the role of the major rival powers of the United States of America, which began to operate in the region, increased at the expense of the decline in the American role and influence (Abdullah, 2015).

\section{Jordan and the United States of America goals from the bilateral relationship:}

This section discusses the goals of Jordan and the United States of America in their bilateral relations, and contributes to identifying and analyzing their goals within these relations.

\section{First: Jordanian goals in its relations with the United States of America:}

It can be said that the most important objectives of Jordanian foreign policy in its relations with the United States of America are the following (Al-Hayajana, 2006):

1- The political and security objectives of Jordanian-American relations: This includes preserving the stability of the political situation in Jordan, through American-Jordanian security cooperation, JordanianAmerican military exercises, and securing Jordan economic and military assistance, Which covers a big part of the expenditures that Jordan faces to keep the state's work at the same level and maintaining a good level of effectiveness, which is closely related to the legitimacy of the political system. It also includes strengthening Jordan's security future, and preserving the supreme national interest, by contributing to the establishment of an independent Palestinian state through negotiation between Israel and the Palestinian Authority. Jordan is trying to play a role in establishing a Palestinian state through negotiations with the Israelis through Washington, and the presentation of the road map was a Jordanian initiative at first, but it was represented by the US, also Jordan believes in the fundamental and central role of the US in achieving Palestinian state building, because failure to establish a Palestinian state will pose a direct threat to Jordan, Especially the implementation of the "transfer" project, and the application of the Israeli extreme right wing theories, which holds that Jordan is Palestine; Jordan rejects any solution to the Palestinian issue at its expense, just as building the separation wall practically threatens the establishment of a Palestinian state, but rather makes it impossible, and Jordan will be the alternative homeland, and this is what Jordan rejects on all levels and on all occasions.

2- Economic objective: The Jordanian state focuses on the economic side in its relations with the United States of America, and highlights the importance of Jordanian-American economic relations by signing the American Free Trade Agreement, and linking economic relations to political relations, Especially the bilateral link in Jordanian-Israeli relations through the establishment of the Qualified Economic Zones, and the total bilateral American aid (supervised by the state and the United States Agency for International Development) to Jordan until the fiscal year 2016 reached about $\$ 17.108$ billion. And the receiving of more American aid to Jordan through security assistance accounts for the Ministry of Defense, Jordan has received \$ 774.6 million in additional military aid since FY 2014 (Al-Shahr, 2017).

3- Regional goal: trying to persuade the American side to adopt the Jordanian position in its foreign policy towards the Arab region to restore the Jordanian regional role, as it was clear that Jordan as a major player in the region is the source of its survival, therefore Jordan's credibility and balanced diplomacy enables it to play an influential regional role It can be beneficial to Jordan.

Based on the foregoing, these goals, which the Jordanian side is trying to achieve, constitute a strategic dimension in the Jordanian relationship with the United States of America, some of which have been achieved, Some are still awaiting to be accomplished, while others are continuous targets that require Jordanian decisionmakers and diplomacy to reconsider some strategies in order to achieve them under an international system governed by the US.

\section{Second: The American goals of its relations with Jordan:}

According to an American report on Jordanian-American relations, it indicates a number of important and pivotal matters for Jordan in relation to the United States, which are (Prados, 2003):

- The Jordanian-American cooperation in security issues, regional and international, without the presence of formal agreements between the two countries, which gave high credence to Jordan.

- The moderate Jordanian policies throughout its recent history.

- Jordan pursues policies in harmony with the West. 
- The stability of the political leadership and political system in Jordan, despite crises and regional turmoil.

- The advanced level of Jordan's population, which contributed to building the Arab region, especially the Arab Gulf states.

- The Jordanian contribution to the stability of the region in security, and to the development of the Arab Gulf states.

- Jordan's decisive and influential role in the peace process in the region. following:

The most important goals of the American foreign policy from its relations with Jordan are the

1- Preserve Jordan's important role as a moderate country in the region, and as a key partner in a Middle Eastern security system.

2- Achieving mutual interests with the United States of America in the Arab region, where Jordan is an important entry point to the United States in the region.

3- Maintaining Jordan's crucial role in countering terrorism, and security cooperation with the United States in pursuing terrorists.

Therefore, Jordan is considered as a strategic importance for the United States of America, and based on the basic principles of international relations, the existence of these common goals is necessary, but not enough, unless it is not accompanied by additional efforts to build and strengthen bilateral relations based on achieving common interests.

Based on the foregoing, the Jordanian-American relations are based on common interests that serve both parties, as each side seeks to exchange its advantages in order to achieve its goals, and notes the important role of the Palestinian-Israeli conflict as a pivotal and interpretive factor for Jordanian-American relations, and the implications of this conflict for Jordanian domestic politics and the American regional presence will affect the course of future relations in Jordan, knowing that Jordan focuses on its national interests, especially achieving comprehensive development.

However, this comprehensive development is linked to the fate of the Palestinian issue, as some consider it an internal factor for Jordan, especially the dimension related to refugees and their fate in the final status issues agreement, in addition to the threat in the matter of "transfer" of the Palestinians to Jordan, and it is noted that the American role in it is pivotal.

Jordan understood that American foreign policy does not change in principle with the change of the American presidency and that dealing with the Democratic or Republican parties is in the interest of Jordan, and it is not wise to take the side of one at the expense of another, It can be said that the Republican and Democratic parties are branches of one party, which is the American party, especially the American foreign policy in the Middle East, and that the Jordanian political leadership understood the decision-making mechanism in the United States of America, the role of Congress, the role of public opinion, the role of pressure groups, and the role of personal or public relations with the American public and opinion leaders, and how the American public thinks. Therefore, any visit to King Abdullah II is not without important media meetings, meeting with decision makers and opinion leaders, and an attempt to form personal relations between Jordan officials and American people in order to serve Jordanian interests, and there is a good impression of the Jordanian leadership and its rule. As happened on one occasion, a reporter asked King Abdullah about security in Jordan, the king replied: "that Jordan is safer than Washington DC, the American capital". Which indicates the King's knowledge of how Washington is a violent city.

Jordan is well aware that foreign policy-making in the United States of America regarding the Middle East is not taking place in the State Department, and that the US State Department is one of its participants, but at a certain level, at least since the events of September 11, as the importance of the Middle East region makes it an issue in the President hands and his advisers in the White House, It is from this basis that the Jordanian visits to the White House intensified, in which the neo-conservatives take the role of the Jordanian Ministry of Foreign Affairs except in coordination operations, since Jordan fully understands that the American President is the one who manages foreign policy in the region. Therefore, this explains many of the Jordanian tendencies to rely on holding summits with the top leadership levels in both countries.

\section{The decline of the American role in the Arab region and its repercussions on Jordan:}

The Arab revolutions had a prominent role in showing the American retreat as an approach, as these revolutions forced the United States to reconsider its foreign policy towards the Middle East and change its strategy using the tools of "soft power", Which was demonstrated in the attempt of the American administration to avoid collision with the trends of Arab public opinion and deal with it positively, Especially with regard to intersections with Islamist movements that have reached power through elections in a number of Arab countries, and trying to contain the results of their expansion. What has been termed the Arab Spring revolutions has 
proven that the US administration is moving according to purely strategic geological frameworks, because the arrival of what may be called "revolutions" to geopolitical axes known to be important hubs for American national security, any change in it may cause a change in the global balance of power that will not serve the national interest of the United States of America, since controlling the Middle East region will open all doors to global control, which is inconsistent with the global domination project of the United States of America. Barack Obama's diplomacy has not brought any new things in its dealings with the Palestinian issue, as the two-state solution, and the promise to establish a Palestinian state, in the end they are purely Israeli proposals, and there is a kind of ambiguity in American policy towards the Middle East, so this region is not always considered as of relevance compared to domestic politics, as the Israeli lobby plays a major role in making the balance of power tilt to its favor, its policies in Palestine in particular, and in the Middle East region in general (Policy Analysis Unit, 19: 2017).

Despite the identification of five major goals of the United States in the Middle East represented it: Reviving US-Arab relations that were badly damaged after the war on Iraq, achieving a major breakthrough in the peace process in the Middle East by pushing Israeli Prime Minister "Benjamin Netanyahu" to freeze settlement construction, to achieve stability in Iraq before the departure of the American forces, to withdraw from Afghanistan with keeping the position of strength and on the basis of minimal political rapprochement with Pakistan, and to initiate a dialogue with Tehran on its nuclear program, However, by examining these goals and comparing them with what is happening on the ground we realized the diminishing of American ambitions year after year regarding the Palestinian issue, while its support for the positions and policies of the Israeli side has continued, as this support has grown a lot, As for the strategic harvest in Iraq, all official American data confirm this fictional narration about the completion of the mission of withdrawal, according to Obama's calculations. However, the reality is very different, as the United States did its best to keep about twenty thousand soldiers deployed in Iraq until after December 2011, because the situation in the country is still far from stable, and this, of course, is for an understandable interest in negotiating a new agreement with Authorities in Baghdad (AlShaher, 2017).

In addition to the way on how to deal with the remnants of the so-called Arab Spring, the remote air strike in Libya expressed the American desire to keep the burdens between the allies, Despite its success, however, it doesn't has a plan on how to deal with its post affect, and does it require another strike or not? Here we note the hesitation that characterized the American foreign policy in dealing with the crises of the Arab Spring during the rule of Barack Obama. "Vali Nasr" also sees in his book: "The Decommissioned Nation: American Foreign Policy in Retreat". That the United States dealt with what was called the wave of the Arab Spring and its policy towards the region, the American position on the region and the movement that characterized it, was a rhetoric filled with hopes and aspirations that it did not find a way to implement on the ground, He also mentioned the fluctuating American position on the developments of the "Arab Spring" between supporting political systems at one time and support for rebel peoples at other times (Nasr, 2013: 24).

President Trump raises the slogan of the United States of "America first", and announces the withdrawal of the United States from the Trans-Pacific Trade Partnership Agreement, and from the Paris Climate Agreement signed by his predecessor Obama, and threatens the United States not to fulfill its commitment to defend the countries of NATO. and demands to renegotiate the North American Free Trade Area agreement that brings his country together with Mexico and Canada, all these indicators made one of the allies of the United States, which is German Chancellor Merkel, to talk about that Europe states can no longer rely on American leadership, and it can be asserted that the diversity in the political, social and cultural structures in the United States of America will represent a constraint on US President Donald Trump, It is clear that American policies will go towards relying on hard power, such as the use of military force, air strikes, and sanctions. Instead of relying on the soft power that Barack Obama, the former president of the United States of America, used as a trend toward negotiation, diplomacy, and support for the values of freedom, democracy, and development support (Ali, 2017).

The Americans are investing their relationship with Jordan in order to interfere in the Syrian crisis directly or indirectly, like what happened during the period of conflict between the Syrian regime and the Muslim Brotherhood in the eighties. From here, the Jordanian-American relations were launched at the beginning of Jordan's position rejecting the communist extension and opposing the influence of the Soviet Union for ideological reasons. Then, from the US interest in Jordan for strategic reasons, as it has a distinct geographical location from which it can benefit from the implementation of its foreign policy in the region. The Hashemite Kingdom of Jordan has achieved several benefits from its relations with the United States, as American aid has enabled it to overcome its economic crises, and helped it to advance its infrastructure and development, and to build its armed forces. It is also noted that this assistance was provided to Jordan in response to pressure from political and geo-strategic factors. The former US ambassador to Jordan, Alice Wells, has pointed out, since Donald Trump's victory in the Republican presidential nomination, regarding the relations between the two countries, that her country's commitment to Jordan is consistent and not negotiable, Despite 
who's going to be the next president, As for the frank message, Trump's commitment during his election campaign was to enhance cooperation with King Abdullah II, in the face of militant groups in the Middle East, This confirms that there are no concerns at the level of political decision makers about changing the US policy towards Jordan, where the interests of the two states intersect with common goals and important files, as there is no alternative to cooperation between them within specific strategies (Levant Institute for Studies, 2016).

The US supported the right to peaceful demonstration in Jordan, but at the same time it defended economic and political reforms of His Majesty King Abdullah II, including raising the prices of fuel and oil derivatives due to the high international price, which led to popular protests in the Kingdom, State Department spokesperson "Victoria Nuland" has called for a commitment to the safety of these demonstrations. "There is always pain associated with such things, but it is necessary pain in this case," Nuland said. The United States supports gradual reform and considers it an appropriate road map, to make itself a participant in the internal debate in Jordan, as it does not wish to provide additional assistance to the Jordanian government, and seeks to avoid this, and does not want Jordan to withdraw its ambassador from Tel Aviv, especially with loud voices demanding the withdrawal of the Jordanian ambassador from Tel Aviv (Washington (D.P.A.)) (2012).

Jordan is considered, like other countries, to have its issues and problems, as it is a newly formed country in terms of time standard, and it is of a special nature in terms of population structure. It also has a leadership with deep historical, religious and civilizational references that imposed on it a kind of pressing political behavior. Jordan has realized that it must face the challenges to achieve its national goals, and that it must search for solutions to its problems within a short period; because delaying this creates more difficulties, and increases the dangers that addressed, at some stages, its existence as an independent and sovereign state (Hadrami and Adwan, 2003: 167).

\section{Jordan long term plan in its relation with the US}

The Jordanian long term plan for its relation with the United States stands out by sticking to the desire to look to new horizons that inspire optimism for the future. This optimism is based on the continuation of the acquisition of benefits and the exchange of interests, and the establishment of a true partnership with human and moral orientations, In order to achieve the gains and reassurance of fair transactions between the two parties, through communication and dialogue, to overcome the inequality between the two parties due to the Jordanian need for American economic and military support and assistance. The nature of the Jordanian vision for the future of relations with the United States stems from the desire to preserve the role that Jordan plays in contributing to stabilizing the influence of the United States in the Middle East region, as it is the global superpower capable of playing great roles in relation to the following: (Al-Fayez, 2013)

The political side: The active contribution in supporting Jordanian efforts to achieve comprehensive development based on the processes of political development and political reform, assigning and supporting the objectives of Jordanian foreign policy related to issues of concern to the Jordanian and American sides towards Arab issues, Such as those related to the situation regarding the events in Syria, and in particular the active contribution to alleviate the pressures on the Jordanian economy due to the increasing number of Arab refugees coming from Iraq and Syria through allocating humanitarian aid to contain the suffering of these refugees.

The economic aspect: Serious work to devise mechanisms to promote upgrading the Jordanian economic reality, which suffers from a major imbalance due to its exposure to many structural problems, the weakness of state treasury resources, and the growing budget deficits due to government support for important sectors within the economic activity.

The military side: meeting the Jordanian armament demands related to the tactical combat weapons that settle the battlefield, in order to fulfill Jordan's desire for its armed forces to interact with all the developments in the world. What is remarkable about the issue of Jordanian-American relations is the negative stance that the American administration stood with regard to the Jordanian desire to build a nuclear reactor for peaceful purposes. The Saudi newspaper, Al-Madinah 2010 published news that the United States informed Jordan through diplomatic channels of this threat, after the head of the Jordanian Atomic Energy Agency "Khaled Toukan" failed to obtain the approval of the United States of America for the nuclear program after six months of talks. According to the newspaper, the American position on the Jordanian peaceful nuclear reactor project came after Jordan rejected all Israeli requests to involve it in extracting and enriching Jordanian uranium (AlArab News in 2010).

It is concluded from the above that King Abdullah II was the first Arab leader to meet US President Donald Trump in January 2017, and that the King imposed his agenda and vision on the new American administration, so Jordanian-American relations are governed by a set of internal and external factors that interact with each other, to produce changing and interacting images, depending on the circumstances and the nature of international issues that are undergoing constant changes, and there are regional factors that in turn affect the course of relations between the two countries. 


\section{Summary}

This study is based on the main hypothesis that: The Arab Spring revolutions affected the orientations of the American foreign policy towards the Hashemite Kingdom of Jordan, as it became clear through the study that the American foreign policy towards Jordan is based on firm foundations aimed at protecting American interests in Jordan, Where the United States views its relationship with Jordan through a set of goals, including, for example, the mutual and comprehensive goals in achieving lasting peace in the Middle East, so it appreciates the Jordanian leadership's role in advancing the peace process and moderation in the region. Jordan is encouraged to confront the violent extremism threatening its security and the region. The United States also appreciates the strong interest in Jordan's active contribution in countering terrorism, which indirectly helps the United States in maintaining its vital interests in the Middle East region. That relationship contributed to strengthening Jordan's commitment to peace, to stability, and to moderation, and this Jordanian commitment facilitated the process of providing American economic and military aid to Jordan, The political cooperation between the United States and Jordan has resulted in Jordan maintaining its stability and prosperity, the principles and interests in American foreign policy are not separated with regard to the Arab Spring countries in general. As it was not the one that directly created the revolutions, it was a consensus of popular will and American interests, as it dealt with them with clear fog, and positions varied, it stood beside the party that achieved the greatest degree of its interests, on the pretext of its support for any democratic transformation produced by the revolutions, forcing it to deal with the political Islam systems in an attempt to overthrow it internally because of the different intellectual foundations and policies, even if the interests converged.

\section{Results:}

The study reached the following results:

1. The American interest in developing strategic relations with the Hashemite Kingdom of Jordan is based on security, strategic and political dimensions, and is linked to Jordan's role in the Arab region as a strategic ally of the United States of America, It was expressed by the United States of America with economic and military support, in order to improve Jordan's capabilities and contribute to alleviating the burdens on it. Until it becomes a strategic ally of the United States from outside the framework of NATO, in recognition of its efforts to bring peace, and its great role as a factor of security, stability and balance in the Middle East region, The influence of the events of September 11, 2001 was also highlighted in support of the political reform process, the promotion of democracy, political participation and women's rights, This was evident from the presentation of the Greater and New Middle East Project, and Jordan was one of the Arab countries that worked on undertaking important political reforms that strengthened the process of democratic transformation in Jordan.

2. The study showed the presence of an influence of military factors on Jordanian-American relations, as demonstrated by the Jordanian role in countering terrorism and extremism, Jordan's participation in alliances against terrorism, and the role of the Jordanian armed forces participating in international peace-keeping forces and supporting stability in the Arab neighboring countries, in addition to protect the Jordanian-Israeli borders.

3. Jordan is at the same time a buffer between Israel and both Iraq and Syria, and between the Red Sea and Mediterranean regions, and this site has given Jordan a strategic importance that exceeds its geographical size, made it in the focus of US attention. So the United States is committed to Jordan's security, and in close partnership with it, to addressing common security challenges. The US military has a long-term relationship with Jordan, to develop the capabilities of the Jordanian armed forces, enhance border security, support peace-keeping operations, and counter-terrorism efforts. However, for security reasons, Jordan's stability is important to America's strategic interests in the region, but this stability comes to meet aspirations The Jordanian people, and make reforms.

\section{Recommendations:}

After showing the results of this study, it recommends the following:

1- The United States of America can redraw its foreign policies to achieve its goals in the region by:

- Advancing the peace process and supporting the Israeli-Palestinian peace negotiations, because of its objectives in the region and achieving security and stability for Jordan.

- Adopting a policy of mutual interests and interdependence to develop Arab-American relations.

2- The United States of America can enhance its assistance to Jordan in the military and security field and in countering terrorism and extremism, as they are a priority in American foreign policy. 
3- The necessity of strengthening Arab-American relations and Jordanian-American relations and alerting Jordanian foreign policy to a clear strategy in managing Jordanian-American relations to enhance security and stability in Jordan.

\section{Sources and references}

Arabic references:

- Abdullah, Lubna (2015), American Foreign Policy Towards the Syrian Crisis 2011-2014, The Arab Democratic Center

- Abu Karim, Mansour (2017). The most prominent feature of US foreign policy toward the Middle East after Trump's victory. Quoted from the link: http://www.al-bayader./

- Alarab news (2010) www.alarabnews.com

- Al-Fayez, Diyab (2013), Jordanian-American Relations and Their Future Prospects, Middle East University, Amman, Jordan

- Al-Hadrami, Omar and Al-Adwan, Mustafa (2003), National education, home, citizen and political system in Jordan. Amman: Majdalawi Publishing House.

- Alhajaj, Khalil (2009), The Jordanian-American Relationship: A Historical Study on Political Factors and Development Impacts, 1985-1957, Journal of Studies of Humanities and Social Sciences, Volume 36, No. 1, University of Jordan, Jordan

- Al-Hayajneh, Adnan. 2006. "Jordanian-American Relations during the Reign of King Abdullah II: An Analytical Study: 1999-2004". Amman: Al-Ra'i Center for Studies.

- Ali, Lubna Abdullah (2017). The Trump administration and signs of change in American foreign policy, The Arab Democratic Center, citing the link: www.democraticac.de

- Al-Majzoub, Taha, (2001), American Hegemony and the American Presence in the Middle East in the Gulf and the Middle East in the American Empire, Part 2, Cairo: The Middle East Library, 2012.

- Al-Mashagbeh, Amin (2017). Jordanian Foreign Policy and the Syrian Crisis, Al-Dustour Newspaper, Amman, Jordan.

- Al-Shaher, Shaher Ismail (2017). The Middle East in the Shadow of American Foreign Policy Agendas an Analytical Study of the Transition Between Obama and Trump's Administration, Beirut: The Arab Democratic Center for Strategic, Political and Economic Studies.

- Al-Shoubaki, Hadi Mohammad (2004). Jordanian-American Relations 1956-1998. Amman: Al-Ra'i Center for Studies.

- Khasawneh, Ameed Assem (2006). Jordan's relations with the United States of America. Unpublished. AlQuds University, Palestine.

- King Abdullah II Bin Al-Hussein (2007). Our last chance: the pursuit of peace in a time of danger. Beirut: Dar El Saqi.

- Levant Institute of Studies (2016). Jordan and the United States. Cross interests, link: http://www.levantri.com

- Nasr, Fally (2013). Abandoned Nation: American foreign policy is in retreat. Translation: Amr Abdel Ati. Doha: Center for Island Studies.

- Policy Analysis Unit (2012). Geo-strategic balances and interactions and Arab revolutions. Qatar: Arab Center for Research and Policy.

- Rashid, Sameh (2011). Arab Spring the first year, Arab Affairs Magazine. No. 148, Cairo.

- Sharp, Jeremy (2012). Jordan: Background and Relations with the United States, Congressional Research Service, Washington, October 3. 
- Washington (D.P.A) (2012). The United States of America calls for the peaceful demonstrations of Jordan and defends the King's reforms, link www.youm7.com/

\section{Foreign references:}

- Bensahel, N and Daniel L (2004). Byman (Edited) "The Future Security Environment in the Middle East : Conflict, Stability , and Political Change" , Prepared for the United States Air Force, Approved for Public Release ; Distribution Unlimited, RAND Project AIR FORCE .

- Macridis, Roy (1986), "Modern Political Regimes: Patterns and Institutions," Boston and Toronto: Little, Brown, and Company,

- Prados, Alfred B. (2003). Jordan: U.S Relation and Bilateral Issues Foreign Affairs and National Defense Division, January 2. 